The new copyright rules in Europe are a victory for the entertainment industry, but have provoked a storm of worries in the research community

\section{apropos The EU Copyright Directive}

$T^{\text {he new set of rules on copyright be- }}$ 1 gan life in the European Commission in Brussels as an attempt to harmonise the hotch potch of different copyright laws in member countries. The set of rules-called a directive-were also an attempt to update legislation for the digital age taking account of CD Roms, Digital Video Discs, and the Internet. The directive brought protests the moment it was penned, and even before.

Supporting the directive was the music industry (see right). But protesting against the directive, among others, were groups worried about its affect on the disabled (and their access to audio or visual material), librarians worried about its affect on their relationships with publishers, and telecoms operators worried about its affect on their Internet costs. And once the directive had been studied by the European Parliament in Strasbourg, scientists joined the groups of protestors, the European Science Foundation and the Swiss-based Academia Europaea among them.

The original directive was a comprehensive proposal affecting every area of life where copying plays a part, just as it should be. The proposed laws aimed to protect copyright owners, particularly in light of the availability of online material. There were exemptions, to allow copying without permission (similar to the "fair use" statements of current laws). One such exemption was to allow copying in the name of "illustration for teaching and research...for non-commercial ends". Protesters from the research community however, pointed out that this exemption was not clear enough.

The situation got worse when the European Parliament added its own amend- ments to the directive. To the exemption to allow limited paper copying, Parliament added, "provided that the rightholders receive fair compensation." Sir Roger Elliot of Oxford University points out that this effectively cancels out the "illustration for research" exemption-for every photocopy made in a library, even for private use, a fee must be paid to the author, or publisher.

Another amendment by Parliament encourages libraries to establish licence agreements with publishers. Most research libraries already use licence agreements, but some are worried that the costs of licences will increase due to the agreement-photocopying will incur large fees. When Europhysics News telephoned Elsevier, publishers of the Physica series, they stated they were not happy with the amendment. In their opinion licence agreements should be voluntary and not forced on anyone by government.

The European Parliament voted in favour of the directive in February. The directive now goes to the Council of Ministers for discussion. Parliament will vote a second time in the autumn and it will begin to become law as member states implement it next year. The form and method used to incorporate EU directives into national laws is up to member states. With this directive, members can also decide on whether or not to implement some exemptions.

We all want to be able to visit the library and photocopy an article to read in private. Just where we will stand legally in the future when we do this remains to be seen.

"Transient and incidental acts of reproduction... which are an integral and essential part of a technological process for the sole purpose of enabling use to be made of a work or other subject matter shall be exempted... Such uses must be authorised by the rightholders or permitted by law and must have no economic significance for the rightholders."

Amendment 33 to proposal on copyright, with the European Parliament's amendments in italics

No one wants their property stolen. And when it comes to intellectual property (creative products such as songs and novels) the feeling is the same. In the music industry the theft of intellectual property is called "piracy", an album of music copied without permission from the "owner" of the music is a "pirate" copy. And if there's one thing the music industry says it hates, it's pirate music tapes and CDs, often openly on sale at markets across Europe.

If the music industry hates pirated music, it fears the Internet, and the potential for pirates to let loose electronic music files on the surf. Distributing contraband music across time zones is as simple as setting up a Website. And making "perfect" copies of original music recordings is as easy as downloading a digital file from someone else's Website to a writable $\mathrm{CD}$. As one lawyer has put it, the Internet is one big copying machine. It was with this fear in mind that the music industry was lobbying the European Parliament in early summer 1998.

The objective was to convince MEPs to provide stronger protection for the music industry. The European Parliament was about to examine the copyright rules proposed by the European Commission. The original proposal exempted copying that was "dictated by technology," such as the automatic but temporary caching of files by networks, done when data traverses the Internet. This was in December 1997. By the time the European Parliament had voted on the rules in February of this year, the exemptions had been changed. Permission from the copyright holder would be needed before temporary copies of data could be made by Internet networks (see above).

The music industry had successfully lobbied Parliament. It had partly found support from the software and publishing industries, but it's techniques (a 15minute "roadshow" for MEPs, a petition signed by 400 music artists and handed in by French pop star Jean Michel Jarre) were successful despite the lobbying efforts of those opposed to tough new rules.

Elly Plooij-van Gorsel is in charge of research for the European Liberals, and is one EU Minister who voted against the proposals because she thought the interests of the entertainment industry and its artists were favoured too much in the directive. "The copyright on products is very strong, even on temporary copies, which is very bad for the speed of the Internet. Also, it will be difficult to make copies just for home use," she says (copying an album by the Irish rock group The Corrs's from $\mathrm{CD}$ onto a tape, and taking the tape to the lab to listen alone, will be illegal under the new copyright rules without permission from the owner of the music-this, in its own small way, may affect research in Europe).

When asked whether she thought researchers could ever match the lobbying tactics of the entertainment industry, Plooij-van Gorsel told Europhysics News, "No. Scientific councils can have influence if they lobby at the national level. But I never once saw science organisations lobbying on the directive, although it influences research." 